\title{
The Promise of the Future
}

\section{A Review of the Serials Literature, 2012-13}

\section{Paula Sullenger}

The serials literature for 2012-13 reflects the ongoing challenges faced by members of the serials information chain. Problems with workflow, systems, electronic exchange of information, and control of proprietary information still occur and can be seen documented in the literature. However, the literature also reflects growing determination that this state of affairs can and should change. Serialists are experimenting with new models of pricing and delivery of content. They are developing standards and protocols to facilitate more seamless communication of accurate information. The changes that need to occur and the difficult decisions that need to be made to create this new, well-functioning system can clearly be seen in the literature under review.

$\mathrm{T}$ he serials literature for 2012-13 continues the tradition of being a literature of practice and purpose. Libraries exist in a world of increased user expectations and decreased user tolerance of barriers to access. Libraries also exist in a world of increased complexities in bringing access to users. The long serials information chain is filled with proprietary information, miscommunication, prohibitive costs, inadequate metadata and system incompatibilities that lead to broken links between users and information. These systemic flaws are a major component of the 2012-13 literature. As has been the case with previous reviews, the serials literature describes these flaws in detail and how each actor in the chain is addressing them. A marked feature of this two-year period, however, is an increased attention to overcoming these barriers and forging the links for a streamlined and seamless information future.

The author began this review by compiling an initial group of 118 articles in the 2012 and 2013 issues of three core serials journals: Serials Librarian, Serials Review, and Insights, The UKSG Journal. The author read the abstracts for these articles, then sorted them into several broad categories. She then viewed these articles more fully, one category at a time, and used keywords and subjects from them as a basis for broader searches in Library Literature \& Information Science

Paula Sullenger (psullenger@tamu .edu) is Associate Dean for Information Resources at Texas A\&M University.

Manuscript submitted May 15, 2015; returned to author for minor revisions July 21, 2015; revised manuscript submitted August 12, 2015; accepted for publication September 8, 2015. Index with Full Text and Library, Information Science, \& Technology Abstracts with Full Text. The results of these searches were loaded into RefWorks and sorted into the preliminary categories. As patterns became clearer, additional categories were created and some preliminary categories were collapsed. The author ended with 511 references and began reviewing and summarizing the results one category at a time. The open-access category was extensively culled because of 
the large number of results in the broader database searches. Similarly, discovery and access were addressed in many articles and the author had to pare down to only those that directly affect the work of serials and electronic resources librarians. Although e-books were addressed in the serials literature, the author elected to focus on serials only.

The literature under review covers topics familiar to serials librarians: pricing models, electronic resource management and discovery, licensing, bibliographic control, and usage collection and analysis. This literature is infused with optimism about the future and contains blueprints for getting there. The importance of standards, cooperation, and interoperability take front and center. Virtually all of the literature reviewed addresses electronic resources, while print resources barely receive mention. It appears that for most of the serials library world, the transition to electronic has occurred and is taken for granted. Authors write about print journals mainly to describe what is occurring with legacy collections.

\section{Pricing Models}

Libraries continue to face rising serial prices and flat budgets. EBSCO's 2012 survey found that roughly a third of libraries' budgets for 2011-12 decreased, another third remained flat, while only a third saw increased funds. EBSCO estimated a 6 to 7.5 percent increase in serials prices for 2013. ${ }^{1}$ While commercial publishers continue to take heat for their pricing, society publishers are increasingly becoming the target of scorn by librarians.

Leaving the Big Deal is often mentioned as a means of dealing with rising prices, though many are uncertain if libraries are actually cutting packages or just talking about it. ${ }^{2}$ Glasser describes a method to determine cost per use for journals within five Big Deal packages and then ranks those packages in a simulated cut. ${ }^{3}$ Blecic et al., developed two more involved metrics for quantitative analysis of Big Deals. Both metrics depend on COUNTER's (Counting Online Usage of Networked Electronic Resources) Successful FullText Article Request (SFTAR) figure for journal titles. Using SFTARs and package costs, the first metric compared three Big Deals and ranked according to the value given to the library. The second metric used SFTARs and journal costs to rank journals within a single Big Deal to determine which journals to keep. ${ }^{4}$ In contrast to simulated cuts, Jones, Marshall, Nabe, and Fowler describe cutting Big Deals at smaller universities and the aftermath. ${ }^{5}$ Both analyses found that, contrary to expectations, document delivery costs did not increase much at all. Plutchak, however, reported a doubling of these costs after cancelling the Big Deal. ${ }^{6}$ Despite this talk of cutting, EBSCO reports that more than 60 percent of publishers believe the Big Deals will still exist in five years. ${ }^{7}$
Librarians and publishers are much more willing to experiment with pricing and access models. A given publisher may allow a library to pursue a "small deal" for a core group of its journals using the bundled purchase method. Desired articles outside of that core may be "rented" for a short, set period. Librarians use pay-per-view/token access as a substitute for subscriptions and as a new form of interlibrary loan, one which does not trigger higher copyright fees. ${ }^{8}$ Pay-per-view and token access often come into play after major cancellations and both allow for a hybrid model of content acquisition. Patron use can be either mediated, whereby a librarian reviews requested articles and approves purchases, or unmediated, whereby article purchases are automatically approved. Hosburgh shows one library's experience with both models from the same publisher. ${ }^{9}$ In either case, librarians resign themselves to the fact that they will purchase the same article several times. Busby speculates that publishers may eventually rely on multiple purchases of certain high-demand article for their revenue instead of journal subscriptions. ${ }^{10}$

Michigan State University's (MSU) experiment with pay-per-view access to all journals from one publisher, Multi-Science Publishing, yields instructive lessons. The majority of article downloads are from journals to which MSU has never subscribed. As with interlibrary loan (ILL) articles, the MSU Libraries have no perpetual access rights, nor may they loan their pay-per-view articles. Despite the drawbacks, Sowards advocates further experimentation with purchasing models. ${ }^{11}$

Libraries are not the only ones thinking about the future and experimenting with new models. Hoping to reach users who lack subscriptions or access to institutional subscriptions, the Nature Publishing Group (NPG) experimented with DeepDyve, which allows viewing articles for only a short time. For less than $\$ 4$, a person has viewing rights for twenty-four hours with no downloading, printing, or saving. NPG intends to explore other models of article rentals. ${ }^{12}$ All this focus on article purchasing is no surprise to Anderson, who argues that the journal, while still a useful container, is increasingly less important than the article. ${ }^{13}$

\section{Open Access}

Publishers are experimenting with open access models. Gold open access refers to the model whereby the author (or author's institution) pays a set charge to make the article freely available online immediately and permanently. New journals have emerged in the last few years in which all content is gold open access and there are no subscription fees for these journals. Established subscription-based journals will sometimes accept open access fees for individual articles, while the majority of the content stays behind the 
publisher's paywall. This is called the hybrid subscription model. Some publishers make their subscription-based content freely accessible after a certain period, which can vary by six months to several years, depending upon the publisher or the journal. Publishers such as the American Physical Society publish content under more than one of these models. ${ }^{14}$

Professional societies often rely on member and library subscriptions to cover their journal production costs and use this revenue to support other aspects of their mission. Since wider dissemination of their members' research is the goal of these societies, they are exploring open access as a means to this end. The American Physical Society and the American Meteorological Society report that their members have expressed interest in open access but the societies have not yet found a way to make this approach financially viable. ${ }^{15}$

While most discussions regarding open access revolve around articles, journals, or publishers, the discipline of high-energy physics formed a coalition to investigate openaccess publishing for its journals. Under the Sponsoring Consortium for Open Access Publishing in Particle Physics $\left(\mathrm{SCOAP}^{3}\right)$ proposal, institutions already subscribing to the list of journals would pay those fees to CERN, the European Organization for Nuclear Research, which in turn pays the publishers. Authors will have their articles immediately available as gold open access without the bother of paying the costs themselves. ${ }^{16}$

While some view open access as a relief to journal subscription prices, others point out that this will not be the case if subscriptions are partially or wholly replaced by article processing charges (APCs) that are actually paid by the authors' institutions. Those institutions that are research-intensive could face even greater costs as they pay for all of the costs of publications. Institutions and individuals that are the consumers of research would no longer pay for access to this research. ${ }^{17}$

Hybrid journals have become common but this does not necessarily translate into more open access articles. Bjork's 2012 study of fifteen major journal publishers found they had more than four thousand hybrid journals among them, but fewer than 2 percent of the articles were open access. He found that the higher the APC, the lower the uptake rate. Authors do not appear willing to pay these fees and many sponsoring institutions will not pay APCs for articles in hybrid journals. Instead, they reserve underwriting for full open access journals. ${ }^{18}$ This non-support for hybrid journals was criticized by Zinn, a faculty member and editor of a scholarly journal, at a panel on scholarly publishing. Under such a policy, librarians rather than authors determine where articles are published. Because many purely openaccess journals are new and may not be ranked or lack an impact factor, he feels younger faculty who publish in these journals may suffer at tenure time. ${ }^{19}$

\section{Electronic Resource Management and Discovery}

Electronic Resource Management and Discovery systems (ERMs) continue to dominate serials discussions and workflows continue to be a source of frustration and discussion. Branscome's survey results show wide variety in where electronic resource management occurs and how many people are involved. Her survey also shows that vendor systems predominate, although they are only briefly described in the literature during the period under review. ${ }^{20}$ Czechowski, Fort and Spear detail the implementation of one commercial ERM, noting some areas, such as coverage data, where that system falls short and the library has retained manual processes that they hoped they could replace with the ERM. There is still too much local manipulation of data to make these systems as useful as promised. ${ }^{21}$ Many libraries are on their second or third ERM with open source systems such as CORAL and Drupal being implemented in more libraries. ${ }^{22}$ Libraries are also adapting free products, such as those from Google, in library workflows. ${ }^{23}$ Lupton's description of York University's Managing University Library Electronic Resources (MULER) ERMs integration with the library's public interface demonstrates the flexibility allowed by locally developed systems. ${ }^{24}$ McQuillan provides a description of various standards or guidelines relevant to five major areas of electronic resource management: link resolvers and knowledge bases; work, manifestation and access points; cost and usage-related data; license terms; and data exchange using institutional identifiers. ${ }^{25}$

Limitations of existing ERMs continue to be documented. England found that even with an ERM, many librarians are still storing additional information in spreadsheets, paper files, email records, and databases because these systems do not provide a home for all of the information necessary to manage electronic resources. ${ }^{26}$ Downey describes the prepurchase workflows and tasks that current ERMs do not track. ${ }^{27}$ Carroll et al. describe using a Google calendar to create a renewal alerting system that its commercial ERM could not provide. ${ }^{28}$ Using the cloud to manage information is in its infancy but may be mainstream soon. ${ }^{29}$ Ohler cautions that some of the problems libraries experience with electronic resources workflows and systems may be due to entrenched library practices plus product limitations. ${ }^{30}$

Currently, libraries' integrated library systems, ERMs, $\mathrm{A}$ to $\mathrm{Z}$ lists, link resolvers, and knowledge bases are separate entities which take some coaxing to work together. Wilson gives an overview of five systems recently released or in development that promise to combine most of these elements into one system. ${ }^{31}$ Attention to ERM and flexible, customizable workflows are promised in each of these systems and remain the key weak point in current ERMs, as "ERM system designers often misunderstood workflow 
design., ${ }^{32}$ England and Shipp argue that each type of electronic resource rates its own workflow and system. ${ }^{33}$ Wang and Dawes describe four essential elements of a functioning next generation ILS: "comprehensive (format-neutral) library resources management; a system based on service-oriented architecture; the ability to meet the challenge of new library workflow; and a next-generation discovery layer." ${ }^{34}$ Optimism about these emerging systems is high, with the view that these systems will solve the interoperability problems libraries experience today and take them out of today's world of local spreadsheets and scripting.

Robust, accurate knowledge bases are the key to this future. There are two major efforts underway to create global knowledge bases to address the lack of accurate, timely information in the serials information supply system. $\mathrm{KB}+$ is the United Kingdom's JISC-based system and $\mathrm{GOKb}$ (Global Open Knowledgebase) is the United States' Mellon-funded system. Both aim to create a shared, open platform to store crucial information that currently is only available in scattered silos. A central location would reduce the huge duplication of effort that link resolvers and libraries currently perform. ${ }^{35}$ Data quality for titles varies by publisher and is often lost during publisher transfers. Beals and Harwood's survey of publishers and librarians showed that a majority of publishers do not know when link resolver companies are informed that the publisher is transferring a title to a new publisher. ${ }^{36}$ Diven discusses the benefits that are gained when the end user is kept in mind, and gives a good overview of the challenges involved in relying on a community-based approach. For instance, the scope of the project changes when the knowledge base is intended for use not only by ERM staff but by end users, such as students and researchers. The quality and granularity of metadata (journal versus article, for example), the interoperability of standards, willingness of publishers to share proprietary information, consortial governance, and especially the willingness of individuals and institutions to maintain and update contributed information are crucial to successful projects. ${ }^{37}$

The effect of this lack of interoperability is keenly seen by users. Chen's study of SFX dead-link reports found a variety of errors causing these reports: the articles really were not available; index errors such as incorrect citations; links that go to the journal only; links go to book reviews or other special items; abnormal volume, issue, or page numbers, especially with articles in supplemental issues; confusion between online publication date and official publication date; DOI errors; and missing online content. ${ }^{38}$ Presentation and Identification of E-Journals (PIE-J) is an emerging standard that makes recommendations that address some of these issues: publishers should present content under the original journal title, instead of putting all online content under the latest title; the print and online
ISSNs should be displayed; publishers should use clear and consistent numbering schemes. ${ }^{39}$

OpenURLs dynamically link users from citations to library holdings and have been widely adopted by librarians and information providers. They are known to have high error rates, however, and NISO's Improving OpenURLs Through Analytics (IOTA) is one effort to improve providers' data. The Knowledge Bases and Related Tools (KBART) working group also investigates and identifies OpenURL metadata issues in the serials supply chain. ${ }^{40}$

\section{Licensing}

Perpetual access clauses are still a major concern for libraries. Sometimes referred to as post-cancellation access, perpetual access refers to the library's right to have access to the online content of a journal, for the issues specified in the license, after the library cancels the journal. Beh and Smith reviewed nineteen licenses from major journal publishers for perpetual access clauses and found great variation among the clauses. The ambiguity regarding in what formats the content will be retained, how it will be accessed, or where it will be permanently housed are only some of the difficulties present in accessing the "perpetual" content. ${ }^{41}$ They also raise doubt as to whether all promised content will be available. Calvert describes a cancellation project and the extensive, time-consuming steps taken to obtain promised perpetual access, while admitting that sometimes they did not always succeed. ${ }^{42}$ This uncertainty about future access to journal and other content led to the formation of a Keepers Registry in which several major archiving organizations contribute metadata about the journals they archive. Like the inventories conducted by Calvert and Beh and Smith, the pilot project revealed many inconsistencies in how content is preserved, especially at the issue level. ${ }^{43}$

Libraries are facing new forms of teaching and research that need to be addressed in licenses, such as text mining and MOOCs, while a long-term issue, ADA-compliance, is receiving increased legal scrutiny. ${ }^{44}$ Data mining is another new, complex area of research librarians are asked to incorporate into licenses. ${ }^{45}$

One eagerly anticipated advance in academic licenses is the ONIX-PL standard, which uses an XML database structure to standardize encoding of licensing elements for transmitting that information electronically. Although ONIX-PL has been around for years it has not seen much use in the United States. Under a NISO grant sample, licenses are being encoded and deposited in GOKb. ${ }^{46}$ Time will tell if this effort leads to adoption of the standard by librarians and publishers. 


\section{Bibliographic Control}

Early in 2012, Boehr et al. laid out the differences in AACR2 and RDA in reference to serials, integrating resources, and continuing resources. ${ }^{47}$ They highlight areas where recommended practices conflict with RDA principles, such as the single-record approach. This work was followed by others in 2013 that provided guidance on the changes serials catalogers face. Blythe gives special attention to electronic integrating resources while Bross focuses on CONSER practice.$^{48}$ Culbertson explains the Program for Cooperative Cataloging's (PCC) decision to go against both AACR2 and $\mathrm{RDA}$ principles and recommend provider-neutral records for resources that are available on multiple platforms. ${ }^{49}$

The cataloging literature focuses on metadata as much as on traditional cataloging. In particular, open access (OA) metadata, which describes content that is openly licensed and freely accessible, has captured much attention. There are several flavors of OA metadata. One is simply the cataloging records themselves, whereby libraries make their catalog records freely available for any library to use. Flynn calls for publishers to provide clean metadata to vendors, who can then create high-quality metadata that can be provided to their customers. ${ }^{50}$ Article-level metadata are the subject of a new NISO initiative, developing standard language to denote an article's open access status. ${ }^{51}$

Looking past RDA, linked data are heralded as the new future of cataloging. The Resource Description Framework (RDF) promises to describe relationships between entities, leading to the Semantic Web that is mentioned in almost articles or presentations that refer to the future. The Universal Resource Identifier (URI) is the essential component of turning the conceptual framework into reality. Szeto provides several useful diagrams for visualizing these new relationships. ${ }^{52}$ According to Singer,

linked data is achieved by following four rules. First, a URI is assigned to a piece of data (e.g., an author or title). Second, HTTP protocol is used to look up these URIs. Third, information is provided in a data model such as the RDF standard. Fourth, links to other URIs are included so that the searcher can discover or link to other data. . . . These linkages broaden users search and can connect users to resources or information that had not been linked to before. Unexpected discoveries are made through these serendipitous connections. ${ }^{53}$

The significant difference between traditional recordbased cataloging and cataloging in a linked data model revolves around the existence of discrete records in local databases. In a linked data model, records largely disappear. Rather than downloading and editing, or creating a new record for each item added to the collection, a cataloger would find data readily available about an item, and make statements that link the item to the library, indicating that it is held in the library's collection. The cataloger could also publish any locally specific notes as additional RDF statements. Library systems would in turn pull data from many places on the web to dynamically assemble a display for a user. Different data elements could be pulled together depending on the user's need; no single, consistent record exists, but a "record" is created at the point of need..$^{54}$ The Library of Congress is developing the Bibliographic Framework Initiative (BIBFRAME) with this linked data future in mind.

Using current MARC record-based cataloging standards, an article must be either described discretely as an article or subsumed under the larger journal heading. Krier argues that the Functional Requirements for Bibliographic Records, or FRBR, can be used to describe both the journal and the article as the "work," and the user can determine which entry point is needed. ${ }^{55}$ Differentiating between the print and electronic versions of titles and describing the complex relationships between former, later, and split titles is no longer necessary as links can take the user to any version of the title. Jones specifies several changes to the MARC 21 format that would be needed to bring about this utility. ${ }^{56}$

It appears the charge of describing serials resources will be in a state of flux for some time. Libraries are still a long way from a world of shared bibliographic data that will eliminate the needless duplication of effort with today's world of multiple records for the same item.

\section{Usage and Analysis}

The most commonly used figure for analysis of journal value is the cost per use (CPU). Bucknell provides a thorough analysis of the shortcomings of this method, including: platform choices that affect downloads; editorials, book reviews, and other "light" content may be counted with articles; unexplained usage spikes; usage data lost when journals change publishers; mixing of open-access downloads with paid content. ${ }^{57}$ Despite the known limitations of usage data, including COUNTER data, libraries still collect and analyze them. Wical's and Brown's surveys illustrate how these data are used. ${ }^{58}$ Sometimes COUNTER reports are the major data points or they are only one of several data points used to evaluate electronic resources. ${ }^{59}$ The Association of Research Library's (ARL) MINES (Measuring the Impact of Networked Electronic Services) survey is being implemented more and in one case its methods have been used to create an institution-specific version. ${ }^{60}$

Sharing information is what libraries do, and this continues now even in the usage environment. The University of North Carolina system's central administration mandated 
a return on investment (ROI) analysis for system libraries' electronic journal collections. The method was determined by the system administrators, not the librarians, and not all recommendations that stemmed from the administrators based on this method seemed relevant or feasible to the librarians. ${ }^{61}$ The joint usage data repository may prove useful in the future. JISC has persuaded many publishers to provide a single point of access to journal usage statistics for UK academic libraries. This project reports increased efficiencies in data gathering and opportunities for more extensive data analysis. ${ }^{62}$ Bulut also reports on consortial-level usage data collection and analysis. ${ }^{63}$

Dissatisfaction with the Institute for Scientific Information's (ISI) impact factor is widespread and librarians are finding ways to develop new measures of journal quality. The United Kingdom Serials Group (UKSG) and COUNTER are partnering to develop a journal usage factor based on readership and not the number of times articles are cited. ${ }^{64}$ Black reports on the customized citation analysis he performs on journals of interest to his institution. ${ }^{65}$

"Altmetrics," short for alternative metrics, aim to measure the impact of an article based on its presence in social media. This new measurement avenue boasts faster feedback time, in contrast to the year-long (or longer) delay in traditional measures such as the impact factor. Altmetrics use publicly available data that can easily and quickly be mined. For such a new field there are no standards such as COUNTER and the data gathered is open to many avenues of interpretation. Galligan explores the current situation and the future possibilities of this new tool. ${ }^{66}$ The subjective nature of the data, the wide possibilities of sources, the emerging problem of gaming the measures, possible inflation of measures due to multiple versions (final published version versus prepublication version hosted on an institutional repository), and the many ways the data can be interpreted may remain significant challenges for the immediate future. ${ }^{67}$

\section{Physical Holdings}

With all the attention given to new electronic formats, we cannot forget that the old formats continue to be very much with us. Libraries maintain significant microform holdings and they are still used, even when electronic versions of the same material are available. ${ }^{68}$

The preservation issues with print and microform are nothing new. One format that has time-sensitive pressures is newsprint. The University of Florida found that 70 percent of newspapers reviewed for a Judaica anniversary newspaper project were disintegrating. ${ }^{69}$ Digitizing newspapers directly from the printed newspaper is the preferred method because it produces better copies. However, the significant costs this entails are leading to acceptance of digitizing from microfilm. Metadata for these resources are crucial and difficult. Elstrom and Jensen discuss the trade-offs in choosing file formats. They emphasize that digitization is not a one-time occurrence but that the digital copies must be frequently monitored and transferred to new files. They also describe thoroughly the difficulties in devising proper metadata for a resource that often changes names and may have multiple editions. ${ }^{70}$ Robertson lists this as one of the reasons a serials librarian should be included in digitization projects involving serials. ${ }^{71}$ We will see more in the future about preserving "born digital" files.

\section{Shared Print}

Libraries still have large print collections to maintain. Gallagher and Rathemacher lay out the risks inherent in relying on perpetual access rights for online access, rather than keeping a print archive onsite. ${ }^{72}$ Few want to keep all of their print, however, and serials librarians are forming collaborative partnerships for print journal retention. These often use a "last-copy" arrangement, whereby at least one library in the partnership agrees to permanently keep the print run of a particular title for a specified time. Most of the shared print storage arrangements are regional and based on existing consortia. Some have well-defined collection policies, such as for print runs of JSTOR titles, while others depend on what their members are willing to contribute. For a complete history and discussion of current shared print repositories, see Genoni's excellent 2013 review article ${ }^{73}$ Keift and Payne suggest steps needed to expand these repositories and to make them true collaborative collections that free up libraries' physical spaces for new programs and functions. ${ }^{74}$

Some of these regional repositories have a distributed holdings model: member libraries promise to retain and maintain in their own facilities the print volumes they "claim." The western Canada alliance COPPUL, the American southeast's ASERL, and the American eastern PALCI follow this model. ${ }^{75}$ Another common model is for the consortium to build a single joint off-site storage facility. Even these "joint" facilities may not be a true shared collection, as participating libraries may not be willing to relinquish ownership of materials. Australia's CARM, for instance, was built in 1996 with the agreement that materials sent there would become the property of the consortium and the member libraries could discard their copies of the shared items. The optimistic plans for a shared collection policy for the facility never materialized. When an additional facility was built in 2010, none of the libraries wanted to participate in a shared collection. Instead, they only wanted storage space for their items. ${ }^{76}$

The United Kingdom's Research Reserve (UKRR) is a distributed national repository. ${ }^{77}$ Brown provides an 
excellent description of the problems faced in organizing a distributed shared collection. The difficulty of interpreting holdings information for the same title in several different libraries is particularly illuminating. ${ }^{78}$ Genoni lists the advantages of a distributed arrangement as lower start-up costs and library autonomy in de-duping decisions, while the disadvantages are that member libraries are less likely to actually de-dupe and have less collection management oversight, thereby creating higher costs on a system-wide level. ${ }^{79}$ Alternatively, the Committee on Institutional Cooperation's (CIC) analysis of the pros and cons of distributed and centralized shared storage led to a decision to invest in a centralized facility. The costs involved in building a facility and maintaining it seemed acceptable given that the CIC would retain control of the volumes, be assured of the physical conditions in which they were stored, and assure their perpetual retention, rather than rely on member libraries to adhere to all promises they made. Sandler et al, provide an equally excellent exposition of the management issues involved in a centralized collection. ${ }^{80}$

Three smaller trends deserve mention, as they are likely to grow in importance soon. A new development in the serials field is the evolution of library as publisher. Bakker recounts a joint project between a library and its associated university press to take a former print journal to an openaccess (with moving two year wall) electronic journal. ${ }^{81}$ Robertson and Simser operate library electronic publishing enterprises for both subscription and open access journals. They detail the complexities of establishing new journals and bringing formerly print journals online and working with faculty who are often entirely new to editing and publishing a journal. At both of their institutions the libraries consider open access publishing part of their mission and fully underwrite their costs. ${ }^{82}$ Lefevre and Huwe give two detailed further examples of special collections libraries that have partnered with their respective faculty constituencies to publish unique scholarly content. ${ }^{83}$

Traditional online journals have been adding still images, 3D images, video content, chemical structures, etc. in the last few years. Journals consisting of purely video content are coming into their own, bringing new challenges in bibliographic description, pricing, and subscription models. Stern raises questions of metadata, indexing, discoverability, delivery, display, and preservation in his analysis of these pioneering journals. ${ }^{84}$ Experimentation with nontraditional content is sure to continue.

With tablets expected to outsell PCs and laptops soon, vendors and librarians are poised to move into the world of information delivery via mobile devices. More publishers have a mobile website in conjunction with their regular website, though the content and functionality may be decreased. They may also require a separate click-through end user license. ${ }^{85}$ Mihlrad reports that database providers are more likely than journal publishers to offer complete content. ${ }^{86}$ There are a few journals that exist only in a mobile-readable version. $^{87}$

\section{Conclusion}

While the serials literature remains practical and focused on addressing day-to-day issues, it has always had a spot for future possibilities. True to its down-to-earth nature, the serials literature in the world we can help create is not viewed through rose-colored glasses. It is a clear-eyed critique of what is lacking today and why. It is filled with realistic outlines of how a better serials world would look and careful analyses of what it will take to get there. Shared repositories of information, physical and digital, that can be trusted to be accurate and complete; shared metadata that publishers, vendors, and libraries can use to seamlessly and unambiguously connect users to content; shared bibliographic records that are created only once. This world is still a long way from certain. The parties involved must relinquish control and look to the greater good and not just their own individual needs. Libraries as well as publishers must be willing to give up some measure of control to achieve this hoped-for connectivity.

\section{References}

1. Allen Powell, "Navigating the New Norm: Vendor, Publisher, and Librarian Strategies to Cope with the Changing Information Industry," Journal of Library Administration 52, no. 5 (2012): 374-76, http://dx.doi.org/10.1080/01930826.2012 701112 .

2. Robert W. Boissy et al., "Is the 'Big Deal' Dying?," Serials Review 38, no. 1 (2012): 36-45, http://dx.doi.org/10.1080/009 87913.2012.10765417.

3. Sarah Glasser, "Judging Big Deals: Challenges, Outcomes, and Advice," Journal of Electronic Resources Librarianship 25, no. 4 (2013): 263-76, http://dx.doi.org/10.1080/194112 6X.2013.847672.

4. Deborah D. Blecic et al., "Deal or No Deal? Evaluating Big Deals and Their Journals," College \& Research Libraries 74, no. 2 (2013): 178-93, http://dx.doi.org/10.5860/crl-300.

5. Mary Ann Jones, Derek Marshall, and Sharon A. Purtee, “'Big Deal' Deconstruction," Serials Librarian 64, no. 1-4 (2013): 137-40, http://dx.doi.org/10.1080/0361526X.2013.760389; Jonathan Nabe and David C. Fowler, "Leaving the 'Big Deal': Consequences and Next Steps," Serials Librarian 62, no. 1-4 (2012): 59-72, http://dx.doi.org/10.1080/036152 6X.2012.652524.

6. Rob Van Rennes, "Technical Services Report: Ending the Big Deal: Truth and Consequences. A Report on the ALCTS Continuing Resources Section Program, American Library 
Association Annual Conference, Anaheim, June 2012," Technical Services Quarterly 30, no. 3 (2013): 318, http://dx.doi .org/10.1080/07317131.2013.785805.

7. Powell, "Navigating the New Norm," 380.

8. Steven W. Sowards, "Library-Publisher Experimentation and Partnership in Alternative Models for Journal Content," Serials Librarian 65, no. 3-4 (2013): 309-34, http://dx.doi.org/10 .1080/0361526X.2013.837858.

9. Nathan Hosburgh, "Getting the Most Out of Pay-Per-View: A Feasibility Study and Discussion of Mediated and Unmediated Options," Journal of Electronic Resources Librarianship 24, no. 3 (2012): 204-11, http://dx.doi.org/10.1080/1941 126X.2012.706112.

10. Lorraine Busby, "Contentus Withoutus: Living Contentedly Without Serials," Serials Librarian 65, no. 2 (2013): 133, http://dx.doi.org/10.1080/0361526X.2013.817227.

11. Sowards, "Library-Publisher Experimentation and Partnership,” 324-25.

12. Grace Baynes and Michael Hanson, "Trialing Mobile and Article Rental Access Options for Journal Content," Serials Librarian 62, no. 1-4 (2012): 217-21, http://dx.doi.org/10.10 80/0361526X.2012.652924.

13. Rick Anderson and Kate B. Moore, "Is the Journal Dead? Possible Futures for Serial Scholarship," Serials Librarian 64, no. 1-4 (2013): 72-73, http://dx.doi.org/10.1080/036152 6X.2013.759877.

14. Andrée J. Rathemacher, "ACRL New England Scholarly Communication Special Interest Group Workshop: Open Access and Scholarly Societies: A Panel Discussion about The Opportunities and Challenges," Serials Review 38, no. 2 (2012): 152-53, http://dx.doi.org/10.1080/00987913.2012 .10765445 .

15. Rathemacher, "ACRL New England Scholarly Communication Special Interest Group Workshop,” 154.

16. Ralf Schimmer, "A Road Long Travelled: Is SCOAP 3 Now Arriving?” Insights: The UKSG Journal 26, no. 2 (2013): 13540, http://dx.doi.org/10.1629/2048-7754.73.

17. Nol Verhagen, "Hybrid OA: A Way to Go?" Insights: The UKSG Journal 26, no. 1 (2013): 52, http://dx.doi .org/10.1629/2048-7754.26.1.51.

18. Bo-Christer Björk, "The Hybrid Model for Open Access Publication of Scholarly Articles: A Failed Experiment?," Journal of the American Society for Information Science b Technology 63, no. 8 (2012): 1496-1504.

19. Rathemacher, "ACRL New England Scholarly Communication Special Interest Group Workshop,” 153.

20. Beth A. Branscome, "Management of Electronic Serials in Academic Libraries: The Results of an Online Survey," Serials Review 39, no. 4 (2013): 222-24, http://dx.doi.org/10.1080 /00987913.2013.10766402.

21. Leslie Czechowski, Malgorzata Fort, and Geoffrey Spear, "Implementing a New ERMS \& Link Resolver to Better Manage E-Resources," Serials Review 38, no. 1 (2012): 34, http://dx.doi.org/10.1080/00987913.2012.10765416.

22. Andre Imre, Eric Hartnett, and C. D. Hiatt, "CORAL: Implementing an Open-Source ERM System," Serials Librarian 64, no. 1-4 (2013): 224-34, http://dx.doi.org/10.1080/03615 26X.2013.760414; Amanda Yesilbas and Susan Davis, "Using Drupal to Track Licenses and Organize Database Information," Serials Librarian 62, no. 1-4 (2012): 155-58, http:// dx.doi.org/10.1080/0361526X.2012.652911.

23. Eric Hartnett and Regina Koury, "Using Google Apps through the Electronic Resource Life Cycle," Collection Management 37, no. 1 (2012): 47-54, http://dx.doi.org/10.10 80/01462679.2012.629600; Karen Jensen, “Managing Library Electronic Resources Using Google Sites,” Journal of Electronic Resources Librarianship 25, no. 2 (2013): 115-23, http://dx.doi.org/10.1080/1941126X.2013.785289.

24. Aaron Lupton and Marcia K. Salmon, "MULER: Building an Electronic Resource Management (ERM) Solution at York University," Journal of Library Innovation 3, no. 2 (2012): 105-22.

25. Bob McQuillan, "Gateway to Improving ERM System Deliverables: NISO ERM Data Standards and Best Practices Review," Serials Librarian 62, no. 1-4 (2012): 112-24, http:// dx.doi.org/10.1080/0361526X.2012.652482.

26. Deberah England, "We Have our ERM System, It’s Implemented: Why Am I Still Going Here and There to Get the Information I Need?," Serials Librarian 64, no. 1-4 (2013): 112-14, http://dx.doi.org/10.1080/0361526X.2013.760148.

27. Kay Downey, "Managing Selection for Electronic Resources: Kent State University Develops a New System to Automate Selection," Journal of Electronic Resources Librarianship 24, no. 2 (2012): 128, http://dx.doi.org/10.1080/194112 6X.2012.684558.

28. Jeffrey D.Carroll et al., “Assessing Ongoing Electronic Resource Purchases: Linking Tools to Synchronize Staff Workflows," Journal of Electronic Resources Librarianship 24, no. 2 (2012): 79-90, http://dx.doi.org/10.1080/194112 6X.2012.684330.

29. Denise Branch, "Electronic Workflows: Taking It to the Cloud," Serials Librarian 63, no. 3-4 (2012): 328-30, http:// dx.doi.org/10.1080/0361526X.2012.721739.

30. Lila (Angie) Ohler, "ERM Ideas and Innovations: Thinking Beyond 'The Way We've Always Done It', Journal of Electronic Resources Librarianship 25, no. 2 (2013): 53-60.

31. Kristen Wilson, "Introducing the Next Generation of Library Management Systems," Serials Review 38, no. 2 (2012): 110 23, http://dx.doi.org/10.1080/00987913.2012.10765438.

32. Emma Cryer, "Technical Services Report: Integrating Erms Into the ILS: Systems for Holistic Resource Management. A Report of the LITA/ALCTS Electronic Resource Management Interest Group Meeting, American Library Association Midwinter Meeting, Dallas, January 2012," Technical Services Quarterly 30, no. 1 (2013): 86, http://dx.doi.org/10.1080/0 7317131.2013 .735961$. 
33. Lenore England and Kelly Shipp, "ERM Ideas and Innovations: Flexible Workflows for Constantly Changing ERM Environments," Journal of Electronic Resources Librarianship 25, no. 3 (2013): 220, http://dx.doi.org/10.1080/194112 6X.2013.813312.

34. Yongming Wang and Trevor A. Dawes, “The Next Generation Integrated Library System: A Promise Fulfilled," Information Technology \& Libraries 31, no. 3 (2012): 78.

35. Liam Earney, "Maximizing the Knowledge Base: Knowledge Base+ and the Global Open Knowledgebase," Insights: The UKSG Journal 26, no. 3 (2013): 244-49, http://dx.doi .org/10.1629/2048-7754.71.

36. Nancy Beals and Paul Harwood, "Project Transfer: Findings from Surveys of Publishers and Librarians Undertaken in 2011," Serials Librarian 63, no. 2 (2012): 216, http://dx.doi .org/10.1080/0361526X.2012.701985.

37. Yvette B. Diven, "Communities of Knowledge: Creating and Connecting Resource Metadata," Serials Review 39, no. 3 (2013): 162-66, http://dx.doi.org/10.1080/00987913.2013.10 766386.

38. Xiaotian Chen, "Broken-Link Reports from SFX Users: How Publishers, Vendors and Libraries Can Do Better," Serials Review 38, no. 4 (2012): 223-25, http://dx.doi.org/10.1080/00 987913.2012.10765470.

39. Derek Marshall and Regina Reynolds, "Having E-Journal Title and ISSN Problems? Have some PIE-J!," Serials Librarian 65, no. 1 (2013): 63-68, http://dx.doi.org/10.1080/036152 6X.2013.800465.

40. Rafal Kasprowski, "NISO's IOTA Initiative: Measuring the Quality of OpenURL Links," Serials Librarian 62, no. 1-4 (2012): 95-102, http://dx.doi.org/10.1080/036152 6X.2012.652480.

41. Eugenia Beh and Jane Smith, "Preserving the Scholarly Collection: An Examination of the Perpetual Access Clauses in the Texas A\&M University Libraries’ Major E-journal Licenses," Serials Review 38, no. 4 (2012): 239, http://dx.doi.org/10. 1080/00987913.2012.10765472.

42. Kristin Calvert, "Starting from Scratch on Perpetual Access," Serials Librarian 65, no. 1 (2013): 69-73, http://dx.doi.org/10 .1080/0361526X.2013.800464.

43. Peter Burnhill, "Tales from the Keepers Registry: Serial Issues about Archiving \& the Web," Serials Review 39, no. 1 (2013): 9-10, http://dx.doi.org/10.1080/00987913.2013.10 765481.

44. Andrée J Rathemacher, "Developing Issues in Licensing: Text Mining, MOOCs, and More," Serials Review 39, no. 3 (2013): 209, http://dx.doi.org/10.1080/00987913.2013.10766397.

45. Clara Ruttenberg, "Technical Services Report: Report of the ALCTS Electronic Resource Management Interest Group. American Library Association Midwinter Meeting, Seattle, January 2013," Technical Services Quarterly 30, no. 4 (2013): 428, http://dx.doi.org/10.1080/07317131.2013.819755.

46. C. D. Hiatt, "ONIX-PL: An Adaptable Standard for
E-Resource Licenses,” Technicalities 33, no. 5 (2013): 12-15.

47. Diane Boehr, Regina Romano Reynolds, and Tina Shrader, "The U.S. RDA Test Process," Serials Librarian 62, no. 1-4 (2012): 125-39, http://dx.doi.org/10.1080/036152 6X.2012.652485.

48. Kurt C. Blythe, Wanda K. Gunther, and Kristina M. Spurgin, "Resource Description and Access: It's Really Not so Bad," Serials Review 39, no. 3 (2013): 178-79, http://dx.doi .org/10.1016/j.serrev.2013.07.008; Valerie Bross, Les Hawkins, and Hien Nguyen, "CONSER Serial RDA Workflow," Serials Librarian 64, no. 1-4 (2013): 211-15, http://dx.doi.org/10.10 80/0361526X.2013.760412.

49. Rebecca Culbertson and Les Hawkins. "The Development of the Provider-Neutral E-Resource MARC Record Guide: P-N/RDA Version," Serials Review 39, no. 1 (2013): 62-63, http://dx.doi.org/10.1016/j.serrev.2013.01.006.

50. Emily Alinder Flynn, "Open Access Metadata, Catalogers, and Vendors: The Future of Cataloging Records," Journal of Academic Librarianship 39, no. 1 (2013): 30, http://dx.doi .org/10.1016/j.acalib.2012.11.010.

51. Todd Carpenter, "Progress toward Open Access Metadata," Serials Review 39, no. 1 (2013): 1-2, http://dx.doi .org/10.1016/j.serrev.2013.02.001.

52. Kimmy Szeto, "Positioning Library Data for the Semantic Web: Recent Developments in Resource Description," Journal of Web Librarianship 7, no. 3 (2013): 305-21, http:// dx.doi.org/10.1080/19322909.2013.802584.

53. Ross Singer, quoted in Christine K. Dulaney, "Libraries, Linked Data, and the Semantic Web: Positioning Our Catalogs to Participate in the 21st Century Global Information Marketplace: An ALCTS Midwinter Symposium; ALA Midwinter Meeting, Dallas, TX, January 20, 2012," Serials Review 38, no. 2 (201): 160, http://dx.doi.org/10.1016/j. serrev.2012.05.008.

54. Christine K. Dulaney, "Libraries, Linked Data, and the Semantic Web: Positioning Our Catalogs to Participate in the 21st Century Global Information Marketplace: An ALCTS Midwinter Symposium; ALA Midwinter Meeting, Dallas, TX, January 20, 2012," Serials Review 38, no. 2 (201): 160, http:// dx.doi.org/10.1016/j.serrev.2012.05.008.

55. Laura Krier, "Serials, FRBR, and Library Linked Data: A Way Forward," Journal of Library Metadata 12, no. 2-3 (2012): 177-87, http://dx.doi.org/10.1080/19386389.2012.69 9834.

56. Ibid, 184-85; Ed Jones, "Description of Serials, RDA, and the MARC 21 Bibliographic Format," Serials Librarian 65, no. 3-4 (2013): 295-308, http://dx.doi.org/10.1080/036152 6X.2013.836465.

57. Terry Bucknell, "Garbage In, Gospel Out: Twelve Reasons Why Librarians Should Not Accept Cost-Per-Download Figures at Face Value," Serials Librarian 63, no. 2 (2012): 192 212, http://dx.doi.org/10.1080/0361526X.2012.680687.

58. Stephanie H. Wical and Hans F. Kishel, "Strategic Collection 
Management through Statistical Analysis," Serials Librarian 64, no. 1-4 (2013): 171-87, http://dx.doi.org/10.1080/036152 6X.2013.760394; Jeanne M. Brown and Eva D. Stowers, "Use of Data in Collections Work: An Exploratory Survey," Collection Management 38, no. 2 (2013): 143-62, http://dx.doi.org/1 $0.1080 / 01462679.2013 .763742$.

59. Sarah Sutton, "A Model for Electronic Resources Value Assessment," Serials Librarian 64, no. 1-4 (2013): 24553, http://dx.doi.org/10.1080/0361526X.2013.760417; Sarah Anne Murphy, "Data Visualization and Rapid Analytics: Applying Tableau Desktop to Support Library DecisionMaking," Journal of Web Librarianship 7, no. 4 (2013): 46576, http://dx.doi.org/10.1080/19322909.2013.825148; Susan Hurst, Andy Revelle, and Aaron Shrimplin,"Seeing the Forest by Counting the Trees: Using a Variety of Data Sources to See the Big Picture," Journal of Web Librarianship 7, no. 4 (2013): 434-50, http://dx.doi.org/10.1080/19322909.20 13.835175 .

60. Aaron Lupton and Catherine Davidson, "Assessing the Value of E-Resources to York University Faculty Using the MINES for Libraries Protocol: An Evolving Landscape," Journal of Web Librarianship 7, no. 4 (2013): 422-33, http://dx.doi.org /10.1080/19322909.2013.839849; Terry Reese, "Giving the User a Voice: Capturing Impact through the Interjection of User Impact Surveys Into the Information Retrieval Workflow," Collection Management 38, no. 2 (2013): 163-67, http:// dx.doi.org/10.1080/01462679.2013.765318.

61. Virginia Bacon and Patrick L. Carr, "Assessing Value Through Cross-Institutional Comparisons: A Discussion of the 2012 University of North Carolina System-Wide E-Journal Survey," Serials Review 39, no. 2 (2013): 86-92, http://dx.doi.org /10.1080/00987913.2013.10765499.

62. Jo Lambert and Angela Conyers, "Adding Value to Usage Statistics: The Journal Usage Statistics Portal (JUSP) Enhancements," Serials Librarian 63, no. 3-4 (2012): 305-14, http:// dx.doi.org/10.1080/0361526X.2012.723608.

63. Burcu Bulut et al., "ANKOS Publisher Application System and Its Impact on the E-Resource Evaluation Process," Serials Review 39, no. 1 (2013): 29-36, http://dx.doi.org/10.1080/ 00987913.2013 .10765483$.

64. Oliver Pesch, "Usage Factor for Journals: A New Measure for Scholarly Impact," Serials Librarian 63, no. 3-4 (2012): 26168, http://dx.doi.org/10.1080/0361526X.2012.722522.

65. Steve Black, "Practical Applications of Do-It-Yourself Citation Analysis," Serials Librarian 64, no. 1-4 (2013): 285-98, http://dx.doi.org/10.1080/0361526X.2013.760420.

66. Finbar Galligan and Sharon Dyas-Correia, "Altmetrics: Rethinking the Way We Measure," Serials Review 39, no. 1 (2013): 56-61, http://dx.doi.org/10.1080/00987913.2013.1 0765486.

67. Jean Liu and Euan Adie, "Five Challenges in Altmetrics: A Toolmaker's Perspective," Bulletin of the Association for Information Science \& Technology 39, no. 4 (2013): 31-34.
68. Dana M. Caudle, Cecilia M. Schmitz, and Elizabeth J. Weisbrod, "Microform-Not Extinct Yet: Results of a Long-Term Microform Use Study in the Digital Age," Library Collections, Acquisitions \& Technical Services 37, no. 1-2 (2013): 2-12, http://dx.doi.org/10.1016/j.lcats.2013.02.001.

69. Rebecca Jefferson, Laurie Taylor, and Lourdes SantamaríaWheeler, "Digital Dreams: The Potential in a Pile of Old Jewish Newspapers," Journal of Electronic Resources Librarianship 24, no. 3 (2012): 185, http://dx.doi.org/10.1080/194112 6X.2012.706109.

70. Gry Vindelev ElstrØm and Tonny Skovgård Jensen, "Planning for Mass Digitisation of Newspapers: A Castle, a Shed or Something in Between?" Microform \& Digitization Review 41, no. 3-4 (2012): 129-39, http://dx.doi.org/10.1515/mir -2012-0021.

71. Wendy Robertson and Stephen Headley, "New Life to Old Serials: Digitizing Back Volumes," Serials Librarian 62, no. 1-4 (2012): 181-82, http://dx.doi.org/10.1080/036152 6X.2012.652917.

72. Brian T. Gallagher and Andrée J. Rathemacher, "Need Exceeds Space: A Serials Withdrawal Project at the University of Rhode Island University Libraries," Library Resources \& Technical Services 56, no. 2 (2012): 97. http://dx.doi .org/10.5860//rts.56n2.94.

73. Paul Genoni, "An International Review of the Development and Implementation of Shared Print Storage," Australian Academic \& Research Libraries 44, no. 1 (2013): 50-66, http://dx.doi.org/10.1080/00048623.2013.773867.

74. Robert H. Kieft and Lizanne Payne, "Collective Collection, Collective Action," Collection Management 37, no. 3-4 (2012):137-52, http://dx.doi.org/10.1080/01462679.2012.68 5411.

75. Gwen Bird and Gohar Ashoughian, "All Together Now: Planning for Shared Print Archiving at Canada’s Western Universities," Collection Management 37, no. 3-4 (2012): 26070, http://dx.doi.org/10.1080/01462679.2012.685433; Diane Bruxvoort, John E. Burger, and Lynn Sorensen Sutton, "Like a Snowball Gathering Speed: Development of ASERL's Print Journal Retention Program," Collection Management 37, no. 3-4 (2013): 223-36, http://dx.doi.org/10.1080/0146 2679.2012.685423; Sharon Wiles-Young, Christy Roysdon and John Barnett, "No Substantial Penalty for Withdrawal: The PALCI Shared Print Journal Archive," Serials Librarian 62, no. 1-4 (2012): 79-86, http://dx.doi.org/10.1080/0361 526X.2012.652466.

76. Cathie Jilovsky, “The CARM Centre: The Creation, Revelation and Evolution of a Print Repository," Australian Academic \& Research Libraries 44, no. 2 (2013): 113-24, http:// dx.doi.org/10.1080/00048623.2013.793590.

77. Chris Brown, "Building the UK Research Reserve: Using Coordinated De-Duplication to Create a Collaborative Print Journal Collection," Serials Librarian 63, no. 1 (2012): 38-54, http://dx.doi.org/10.1080/0361526X.2012.684857. 
78. Ibid, 47-49

79. Paul Genoni, "A Distributed National Stored Collection: Testing the Possibilities," Australian Academic \& Research Libraries 44, no. 2 (2013): 75-89, http://dx.doi.org/10.1080/0 0048623.2013 .795474$.

80. Mark Sandler et al., "CIC Co-Investment to Protect Print Research Library Collections in the Midwestern United States," Collection Management 37, no. 3-4 (2012): 237-59, http://dx.doi.org/10.1080/01462679.2012.685432

81. Caitlin Bakker, "Bringing History into the Digital Age: A Case Study of an Online Journal Transition," Serials Librarian 64, no. 1-4 (2013): 263-66, http://dx.doi.org/10.1080/0361 526X.2013.760419.

82. Wendy C. Robertson and Charlene N. Simser, "Managing E-Publishing: Perfect Harmony for Serialists," Serials Librarian 64, no. 1-4 (2013): 118-28, http://dx.doi.org/10.1080/036 1526X.2013.760399.
83. Julie Lefevre and Terence K. Huwe, "Digital Publishing from the Library: A New Core Competency," Journal of Web Librarianship 7, no. 2 (2013): 190-214, http://dx.doi.org/10.1 080/19322909.2013.780519.

84. David Stern, "The Future of Peer-Reviewed Scientific Video Journals," Online Searcher 37, no. 5: 28-32, 49-50.

85. Leigh Mihlrad and Nancy R. Glassman, "Institutional Access to Mobile Resources," Journal of Electronic Resources in Medical Libraries 9, no. 1 (2012): 77-86, http://dx.doi.org/10 $.1080 / 15424065.2011 .651383$.

86. Ibid.

87. Regina Romano Reynolds and Esther Simpson."ISSN for Serials Available on E-Readers and Other Mobile Devices: Issues and Challenges," Serials Review 38, no. 3 (2012): 171, http://dx.doi.org/10.1080/00987913.2012.10765453. 